\title{
AN ELECTRON MICROSCOPIC EXAMINATION OF STREAMERS IN ACID MINE DRAINAGE WATER FROM A PYRITIC MINE
}

\author{
NORIO WAKAO, ICHIRO TANIMURA*, AND HIDEO SHIOTA \\ Laboratory of Applied Microbiology, Department of Agricultural \\ Chemistry, Faculty of Agriculture \\ * Laboratory of Electron Microscope, Iwate University, Morioka, 020 Japan
}

(Received August 23, 1985)

\begin{abstract}
The slime streamers from acid mine drainage water were examined using both scanning and transmission electron microscopes. The acid streamers were composed of innumerable chains of bacterial rods which had a multilayered cell envelope characteristic of gram-negative bacteria. The slime matrix was made up of densely interwoven microfibrils of extracellular acid polysaccharides which stained positively with ruthenium red. The microfibrils varied considerably in thickness and were woven in various patterns in the electron micrographs of thin sections. Characteristic architecture such as lattice structure of electron-dense dots and surface projections were observed in the bacterial cell envelopes. Bacteriophages occurred in the slime matrix of the acid streamers.
\end{abstract}

The growth of copious amount of gelatinous streamers occurs in acid mine drainage water from the abandoned Matsuo sulfur and iron sulfide mine area in Iwate Prefecture. The acid streamers strongly oxidize iron and are autochthonous in the flowing acid mine water which contains a high concentration of ferrous iron (1). We examined the morphological and physiological characteristics of the acid streamers. They were a mass of acidophilic, obligately chemolithotrophic iron-oxidizing bacteria embedded in a gelatinous matrix $(l)$. In this study, using both scanning electron microscope and transmission electron microscope combined with negative and ruthenium red stainings, we investigated the ultrastructural characteristics of the acid streamers and the slime fibrous matrix.

\section{MATERIALS AND METHODS}

Sampling. Streamer samples used in this study were taken from acid water flowing from a waste pile of ore slag at Motoyama and from the Akagawa River 
contaminated with acid mine drainage water from the $112 \mathrm{~m}$ level mine drift in the Matsuo Mine (I). Fresh streamer samples were deposited in screw-capped polyethylene bottles filled with the acid mine water, transported to the laboratory, stored in a refrigerator, and used within $24 \mathrm{hr}$ for electron microscopic examinations.

Scanning electron microscopy. Streamer samples were thoroughly washed in distilled water and fixed for $2 \mathrm{hr}$ in $2 \% \mathrm{v} / \mathrm{v}$ glutaraldehyde in $0.1 \mathrm{M}$ phosphate buffer $(\mathrm{pH} 7.2)$ at $4{ }^{\circ} \mathrm{C}$. The fixed samples were rinsed twice in the same buffer and dehydrated stepwise, through a graded series of ethanol $(40,50,70,80$, and $95 \%$ $\mathrm{v} / \mathrm{v}$ ), with three final changes of $100 \%$ ethanol for 10 min each. Subsequently the samples were placed in isoamyl acetate to remove the ethanol. The samples were then critical-point dried with liquid $\mathrm{CO}_{2}$ (Hitachi HCP-1 critical point dryer), mounted on stubs, and coated with gold in a Eiko IB-3 ion coater. The specimens were examined and photographed in a Hitachi S-450 scanning electron microscope operating at an accelerating voltage of $15 \mathrm{kV}$.

Transmission electron microscopy (ultrathin sectioning). The following procedures (2-4) were used to stain acid polysaccharides for transmission electron microscopy. Streamer samples were thoroughly washed in distilled water and placed in $1.2 \% \mathrm{v} / \mathrm{v}$ glutaraldehyde in $0.1 \mathrm{M}$ cacodylate buffer $(\mathrm{pH} 6.5)$ with $0.05 \%$ $\mathrm{w} / \mathrm{v}$ ruthenium red at $4^{\circ} \mathrm{C}$ for $2 \mathrm{hr}$. They were then washed with three changes of the cacodylate buffer, and postfixed in $2 \% \mathrm{w} / \mathrm{v}$ osmium tetroxide in the ruthenium red-cacodylate buffer for $3 \mathrm{hr}$ at room temperature. After brief rinsing in the cacodylate buffer, samples were dehydrated as described before with two final changes of $100 \%$ ethanol for 10 min each. The samples were further washed two times in $n$-butyl glycidyl ether, and embedded in Epon 812 according to the method of LuFT (5). Stainless controls were prepared by omitting ruthenium red from the fixatives.

Ultrathin sections were cut on a Porter-Blum MT-1 ultramicrotome with glass knives, mounted on collodion-carbon-coated 200-mesh copper grids, stained for $15 \mathrm{~min}$ with $1 \% \mathrm{w} / \mathrm{v}$ uranyl acetate alone. Electron microscopy of the specimens was carried out on a Hitachi HU-125E transmission electron microscope operating at an accelerating voltage of $75 \mathrm{kV}$.

Transmission electron microscopy (negative staining). Streamer samples were also negatively stained by the mixing and drying method with the use of phosphotungstic acid (PTA). Streamer samples were washed thoroughly and fixed in $2 \%$ $\mathrm{v} / \mathrm{v}$ glutaraldehyde in $0.1 \mathrm{M}$ phosphate buffer $(\mathrm{pH} 7.2)$ at $4^{\circ} \mathrm{C}$ for $2 \mathrm{hr}$. After being washed in distilled water, a small mass of the samples were disrupted gently in $2 \%$ w/v PTA, adjusted to a $\mathrm{pH}$ of 6.5 with $\mathrm{KOH}$, with a mortar and pestle. A small drop of the disrupted streamer suspension was placed on copper grids and allowed to stand for $10 \mathrm{~min}$, and the excess of liquid was removed with filter paper. After drying, the preparation was evaporated with carbon in a Hitachi HUS-5 high vacuum evaporator and examined with the transmission electron microscope. 
Chemicals. Ruthenium red (ammoniated ruthenium oxychloride) and glutaraldehyde were purchased from Nakarai Chemicals, Ltd. Epon 812 was from Shell Chemical Co. Osmium tetroxide was from Wako Pure Chemical Industries, LTD. n-Butyl glycidyl ether (commercial name QY-1) and PTA were obtained from Okenshoji Co. and Kanto Chemicals Co., respectively. All reagents were specially prepared for electron microscopy.

\section{RESULTS}

\section{Scanning electron microscopy}

Figure 1 shows scanning electron micrographs of acid streamers. As shown in Fig. 1a, the acid streamers appeared to consist of many fine thread-like structures. The fibers consisted of innumerable bacterial rods which were similar in shape, and the bacterial cells were connected to form long chains (Fig. 1b). The individual microfibrils of streamers were not clearly resolved on the scanning electron micrographs because of the dehydration and drying of the specimens. However, some of the fibrous matrices were coagulated and appeared as masses of film-like material which covered or connected the bacterial cells.

\section{Transmission electron microscopy}

Acid streamers exhibited a network of microfibrils when negatively stained with PTA and examined with the electron microscope (Fig. 2). The microfibrils extended from the bacterial cell (Fig. 2a) and formed a network of tangled fibers (Fig. 2b). The thickness of individual microfibrils on the electron micrographs varied considerably, ranging from 20 to $1 \mathrm{~nm}$ or less.

The ruthenium red staining procedure specific for acid polysaccharides $(2,3)$ was used to examine the fine structure of acid streamers. Figure $3 \mathrm{a}$ is a transmission electron micrograph of a section of acid streamers stained with ruthenium red, showing many bacterial cells enmeshed in an extensive fibrous matrix whose microfibrils were composed of acid polysaccharides. The fibrous materials were not stained in control preparations of the same acid streamers.

The morphological diversity observed in the microfibrous matrix may have resulted from the dehydration and sectioning of the streamer preparations for the microscopy. As shown in Figs. 3a and 4a, many microfibrils were densely interwoven and arranged rather concentrically around bacterial cells. In some preparations, the microfibrils were found to develop at random or extending in the same direction. In most preparations, the microfibrils were extremely fine (about $2 \mathrm{~nm}$ or less) and densely crowded, but a coarse network of relatively thick fibrils (about 10-25 nm) also appeared.

The bacterial cells observed in the electron microscopic preparations were morphologically very similar and had a multilayered cell envelope, which is rather common for gram-negative bacterial cells (Fig. 3b) (6). 


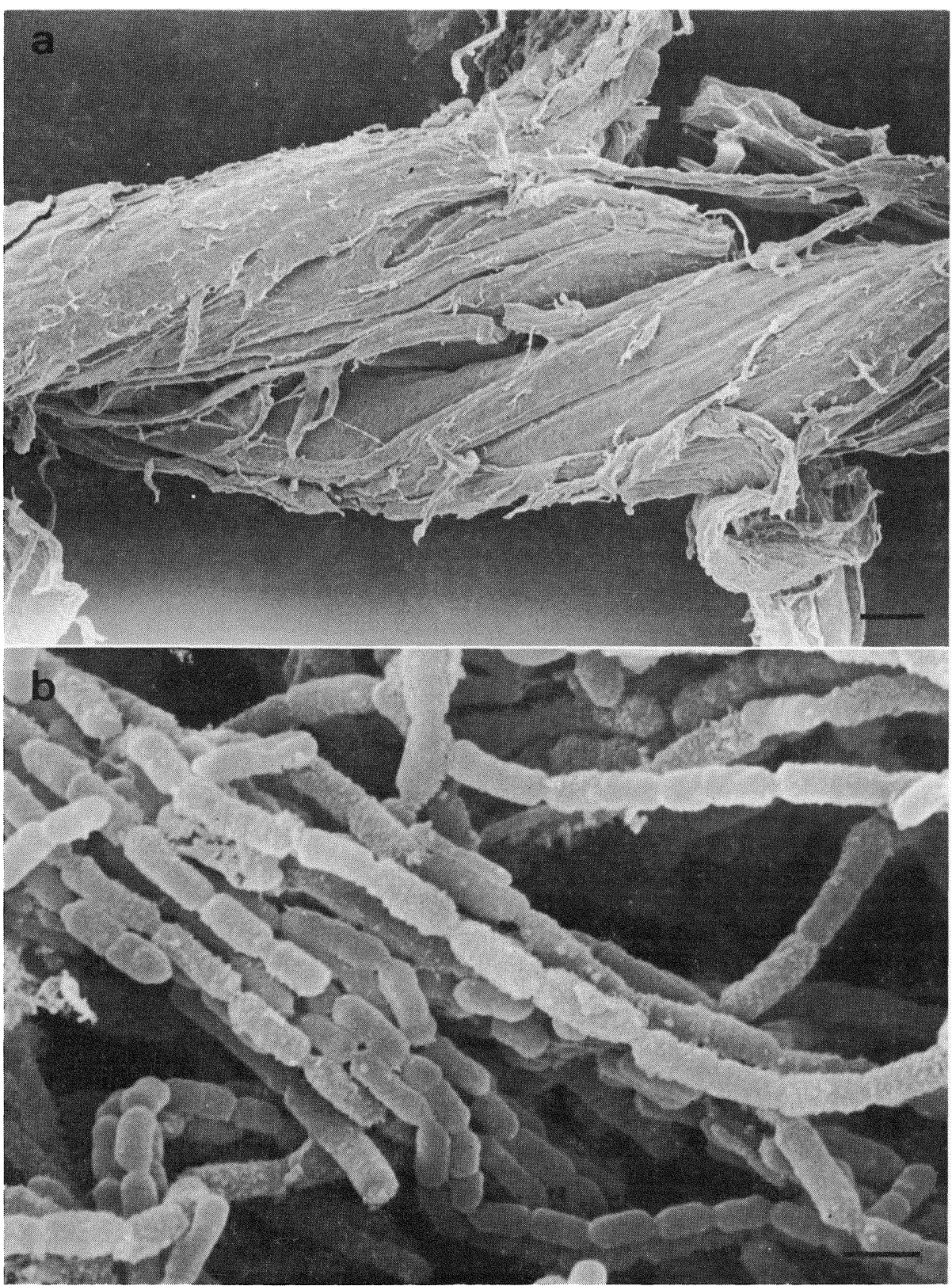

Fig. 1. Scanning electron micrographs of acid streamers showing a thread-like fiber (a) and chains of bacterial rods inside the fiber (b). Bar markers: $100 \mu \mathrm{m}$ (a) and $1 \mu \mathrm{m}(\mathrm{b})$. 

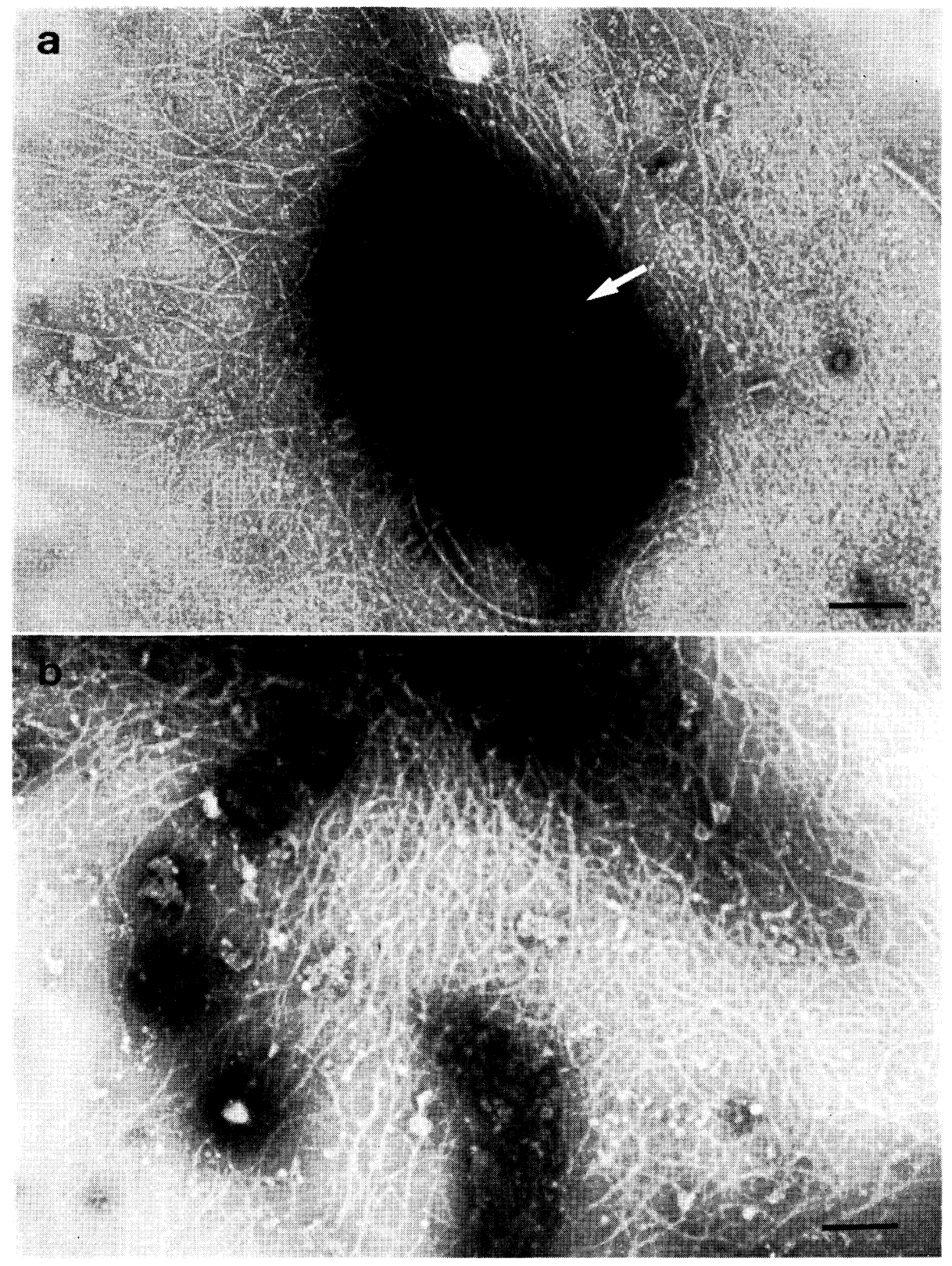

Fig. 2. Transmission electron micrographs of negatively stained acid streamers showing many microfibrils extending from a bacterial cell (a) and an interwoven network of microfibrils (b). An arrow indicates a bacterial cell. Bar markers: $0.25 \mu \mathrm{m}$. 


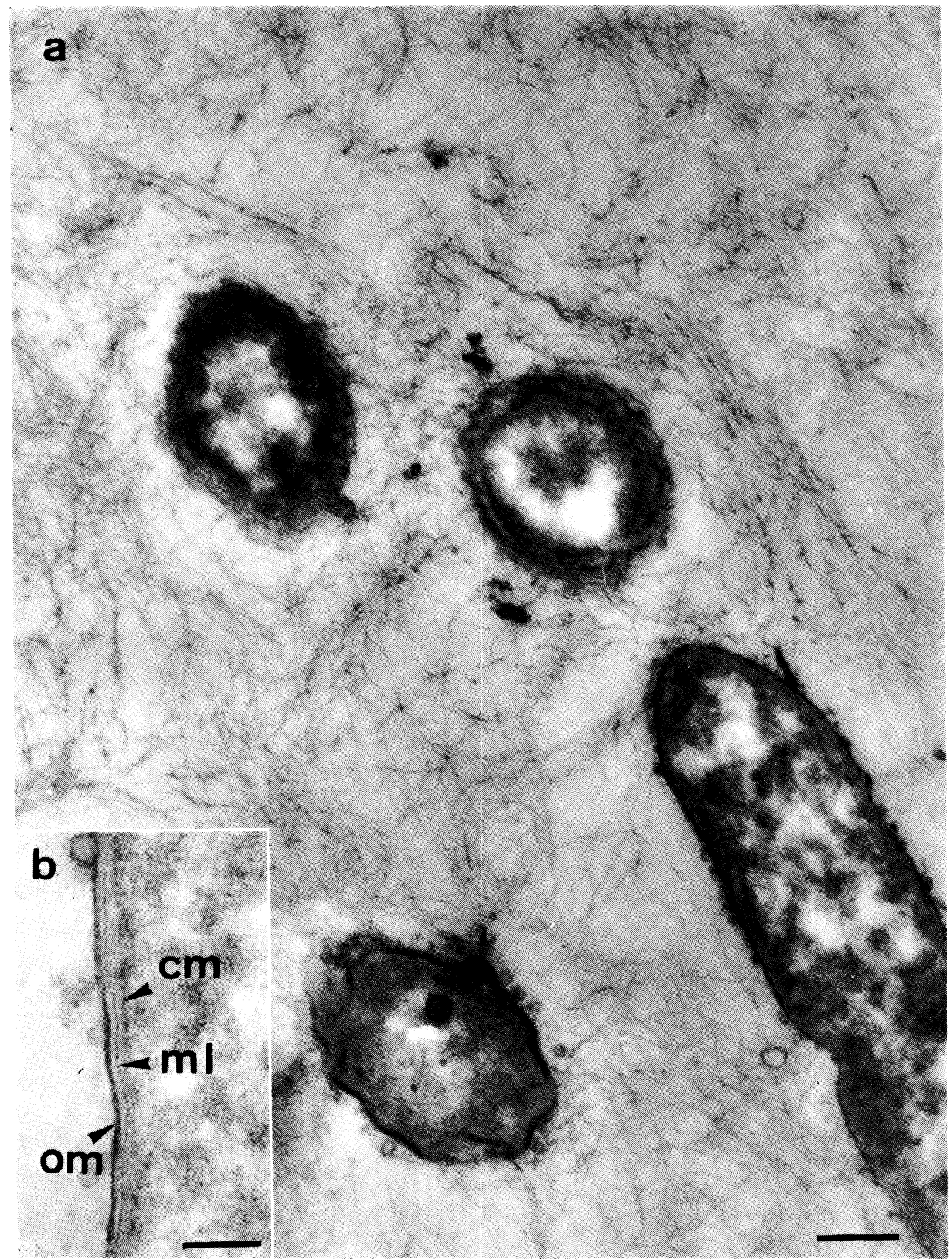

Fig. 3. Transmission electron micrographs of sections of ruthenium red-stined acid stearmers showing an interwoven network of microfibrils around bacterial cells (a) and a multilayered cell envelope (b). om, outer membrane; $\mathrm{ml}$, middle layer; $\mathrm{cm}$, cytoplasmic membrane. Bar markers: $0.25 \mu \mathrm{m}$ (a) and $0.1 \mu \mathrm{m}$ (b). 
The bacterial cells were often surrounded by extracellular electron-dense dots (about 10-20 nm thick) arranged regularly in mono- or multi-layers (Fig. 4a). We think that these dots are made of acid polysaccharides because they were strongly stained with ruthenium red. They probably correspond to the cell wall or the slime capsule of the cell envelope. There was no apparent association of the lattice structure of electron-dense dots with the extracellular fibrous matrix.

The surfaces of bacterial cells in the electron microscopic preparations of acid streamers were characterized by the presence of many projections with double layers (Fig. 4b). The projections were attached to the cell wall and some of them penetrated into the cytoplamsic materials.

Sections of acid streamers contained many electron-dense hexagonal particles with tails (Fig. 5). These were considered to be bacteriophages. They were adsorbed to the bacterial cell surfaces (Fig. 5a) and many of them were distributed around the lysed bacterial cells in a fibrous matrix (Fig. 5c). Electron-dense phage heads were also visible inside bacterial cells (Fig. 5b).

\section{DISCUSSION}

Electron microscopic examination has clearly demonstrated that the acid streamers consist of bacterial rods enclosed within an extracellular fibrous matrix of microfibrils composed of acid polysaccharides positively staining with ruthenium red $(3,7-9)$. It has often been observed that bacteria adhere tenaciously and specifically to the surfaces of various materials in nature by means of fibers of polysaccharides called "glycocalyx" $(10,11)$. The polysaccharide component of the bacterial glycocalyx constitutes a polyanion that stains strongly with ruthenium red $(3,4,10)$. The glycocalyx has a central role in colonization and survival of most bacteria in the various natural environments. In addition to this, it can also function as a food reservoir for bacteria and as a mean of protection from antibacterial agents such as surfactants, antibiotics, bacteriophages and predatory bacteria $(10$, II). We think that the acid polysaccharide microfibrils of the acid streamers are also a kind of glycocalyx. The bacteria of acid streamers can adhere to and colonize the solid surfaces in the rushing stream of acid mine water by spinning a mass of fibers of the acid polysaccharide glycocalyx. However, the functional role of the acid polysaccharides other than adhering the streamers is not yet understood.

Many bacteriophages of hexagonal shape were detected in a fibrous matrix of acid streamers. The surface projections indicated in Fig. $4 \mathrm{~b}$ may also be a kind of bacteriophage adsorbed to bacterial cells. It has been reported that the acid streamers are composed of acidophilic, obligately chemolithotrophic iron-oxidizing bacteria as the original microflora $(I)$. Therefore, the possibility cannot be excluded that the bacteriophages specific to iron-oxidizing bacteria as hosts may exist in the acid streamers. Actually, however, the acid streamers are considered to be 

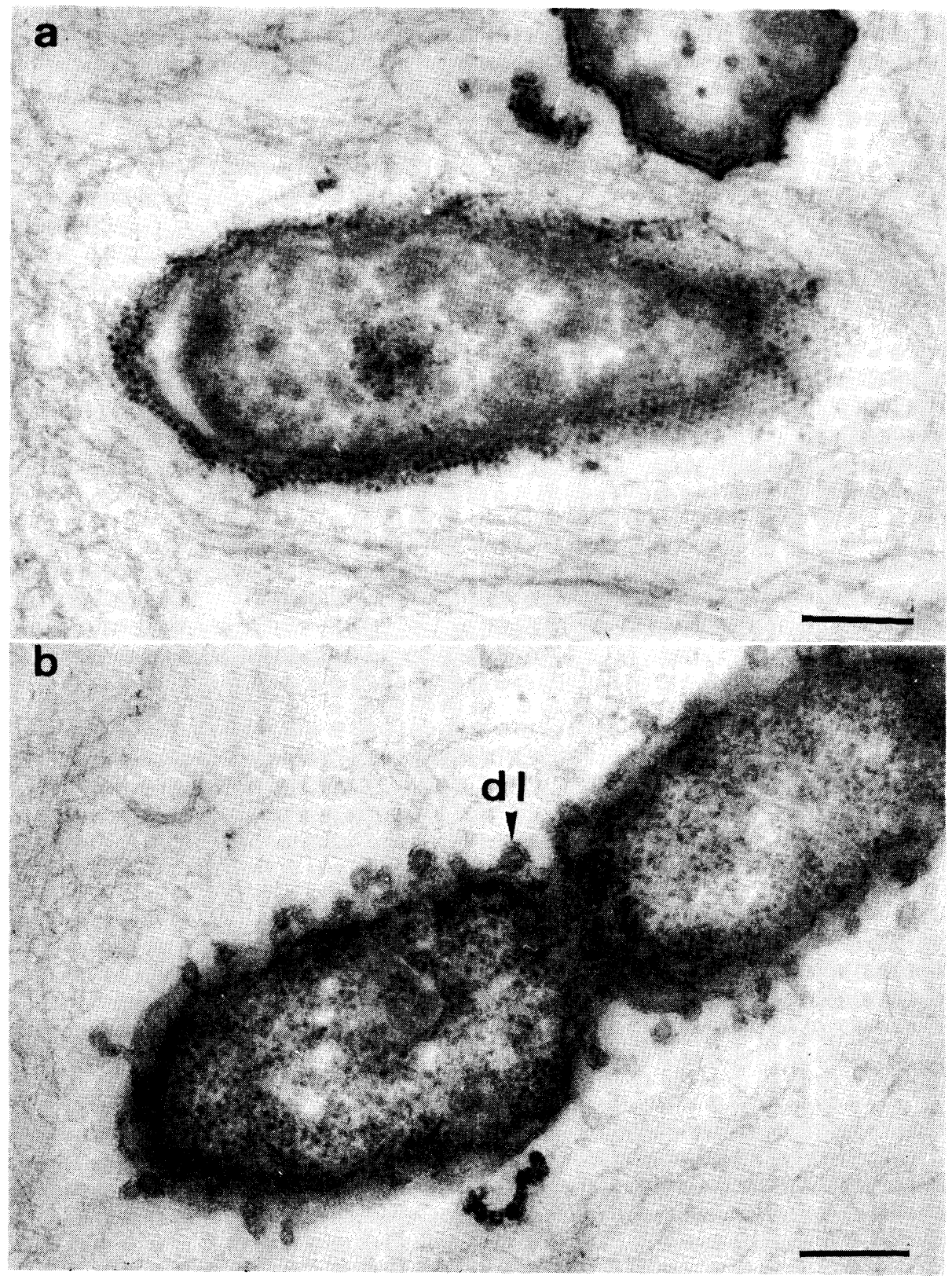

Fig. 4. Transmission electron micrographs of sections of ruthenium red-stained acid streamers showing regularly arranged electron-dense dots surrounding a bacterial cell envelope (a) and many projections at cell surfaces (b). dl: double layer. Bar markers: $0.25 \mu \mathrm{m}$. 


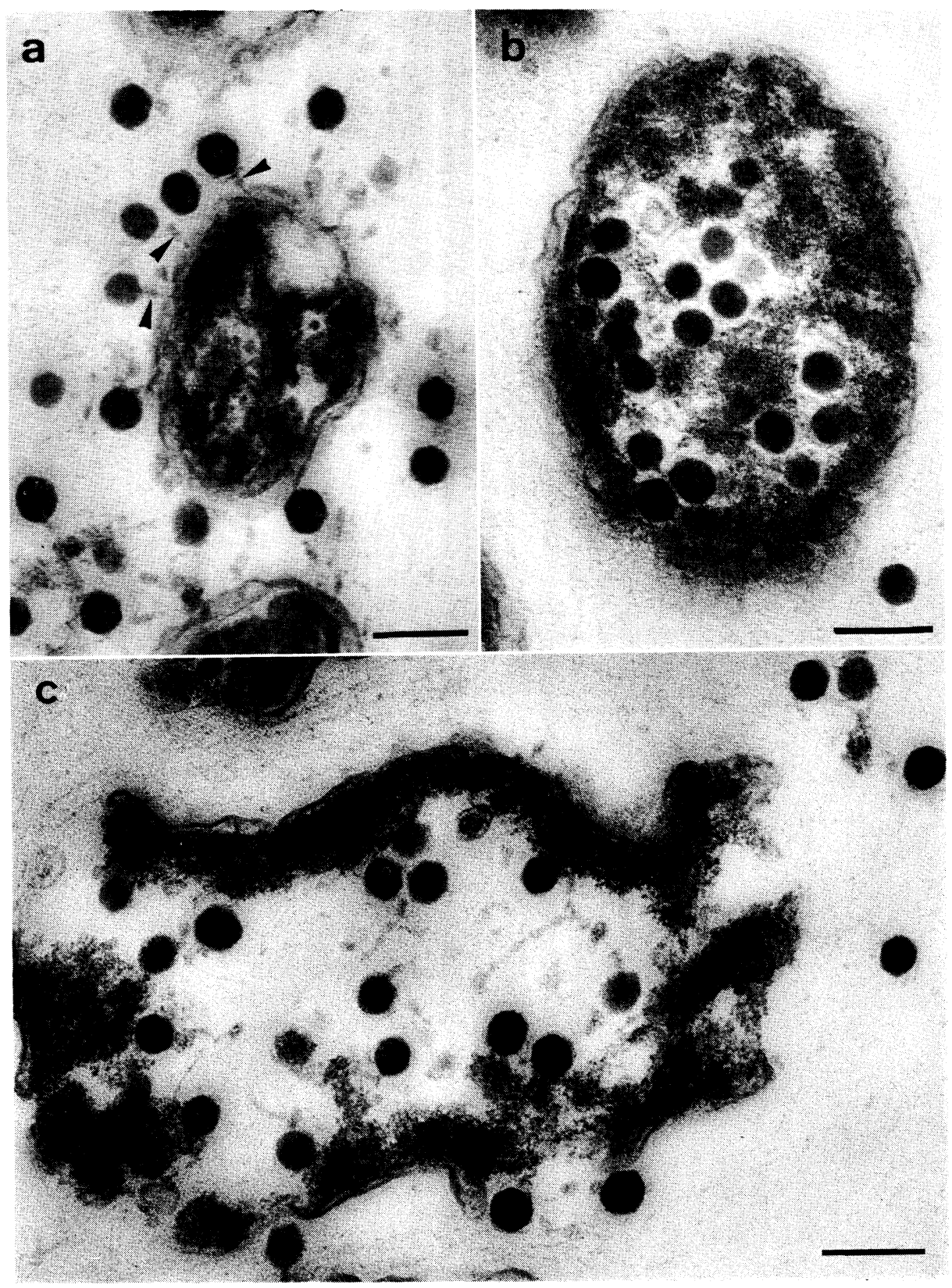

Fig. 5. Transmission electron micrographs of sections of acid streamers showing electron-dense phage particles adsorbed to (a) and inside (b) bacterial cell and distributed around a lysed bacterial cell (c). Arrows indicate phage tails. Bar markers: $0.25 \mu \mathrm{m}$. 
composed of a mixed population of heterotrophic as well as iron-oxidizing bacteria. Therefore, it is difficult in the present morphological work to identify the host of the bacteriophages.

The problems of the function and the sugar components of slime materials, characteristic architectures of bacterial cells and bacteriophages in the acid streamers, are very interesting and worthy of research in future.

\section{REFERENCES}

I) N. Wakao, H. Tachibana, Y. Tanaka, Y. Sakurai, and H. Shiota, J. Gen. Appl. Microbiol., 31, 17 (1985).

2) J. H. LufT, In Electron Microscopy, Vol. 2, ed. by R. UedA, Maruzen Co., Tokyo (1966), p. 65 .

3) J. H. Luft, Anat. Rec., 171, 347 (1971).

4) E. L. Springer and I. L. Roth, J. Gen. Microbiol., 74, 21 (1973).

5) J. H. Luft, J. Biophys. Biochem. Cytol., 9, 409 (1961).

6) J. W. Costerton, J. M. Ingram, and K.-J. Cheng, Bacteriol. Rev., 38, 87 (1974).

7) M. Fletcher and G. D. Floodgate, J. Gen. Microbiol., 74, 325 (1973).

8) H. C. Jones, I. L. Roth, and W. M. Sanders III, J. Bacteriol., 99, 316 (1969).

9) J. L. Pate and E. J. Ordal, J. Cell Biol., 35, 37 (1967).

10) J. W. Costerton, R. T. Irvin, and K.-J. Cheng, Ann. Rev. Microbiol., 35, 299 (1981).

11) J. W. Costerton, G. G. Geesey, and K.-J. Cheng, Sci. Am., 238, 86 (1978). 